\title{
SEASONAL CHANGES IN THE REDUCTION OF BIOGENIC COMPOUNDS IN WASTEWATER TREATMENT PLANTS BASED ON HYDROPONIC TECHNOLOGY
}

\author{
Aleksandra Bawiec ${ }^{1}$, Katarzyna Pawęska' ${ }^{1}$ Krzysztof Pulikowski ${ }^{1}$ \\ 1 Wrocław University of Environmental and Life Sciences, Institute of Environmental Engineering, 50-363 \\ Wrocław, Grunwaldzki Square 24, Poland, e-mail: aleksandra.bawiec@up.wroc.pl, katarzyna.paweska@ \\ up.wroc.pl, krzysztof.pulikowski@up.wroc.pl
}

Received: 2015.12.22

Accepted: 2016.03.04

Published: 2016.04.01

\begin{abstract}
The study presents the results of the treatment of domestic and industrial wastewater with respect to the reduction of nitrogen and phosphorus compounds. The analysis encompasses the results of physical and chemical tests of effluents from two facilities based on hydroponic technology: wastewater treatment plants with hydroponic lagoons using the BIOPAX technology - Paczków, Poland and the Organica technology - Szarvas, Hungary. Monthly treatment effectiveness was determined basing on these analyses. The composition of wastewater flowing into the lagoon (after mechanical treatment) and wastewater discharged to the collector in 2009-2011 was subject to physical and chemical analysis in both facilities. The effluent quality was determined basing on the concentration of total phosphorus, total nitrogen and ammonium nitrogen. Mean annual results of the operation of both objects were high. For the wastewater treatment plant in Paczkow, operating in the BIOPAX technology, the effectiveness of treatment with respect to total nitrogen throughout the analysed period ranged from 76.9-84.4\%. Total phosphorus was eliminated from wastewater with an effectiveness of $96.4-98.0 \%$. Such high reduction level was caused by the application of additional precipitation process in the chambers of activated sludge reactor. The hydroponic plant in Szarvas (Organica technology) was characterised by a high effectiveness of reduction with respect to ammonium nitrogen: 92.0-93.0\%, while the reduction of total phosphorus fell into the range $49.3-55.3 \%$.
\end{abstract}

Keywords: hydroponic technology, treatment effectiveness, nutrients removal.

\section{INTRODUCTION}

Hydroponic wastewater treatment is a technology that enjoys unfading interest among scientists and engineers throughout the world. It is based on using the ability of aquatic plants to uptake biogenic compounds (nitrogen and phosphorus) from wastewater and to use them as fertilizer components intensifying plant growth. Several research has shown that plants are able to survive and grow well in environment rich in high concentrations of biogenes and even heavy metals [Parzych, Cymer et. al., 2015]. Pre-treated wastewater, flowing through the root system of macrophytes, is utilized or at least treated by means of eliminating nitrogen and phosphorus compounds. Such solutions are usually applied in locations where full sewerage of the area is impossible (rural areas), in small home wastewater treatment systems or in facilities accepting wastewater from small districts or public utility objects [Rababah, Ashbolt, 2000]. Such systems that do not use soil substrate may be successfully applied for the production of industrial and ornamental plants, which can utilize flowing wastewater as a source of fertilizer components [Monnet, Vaillant et al., 2002], what results in significant savings during the production. It has also been proven that hydroponic installations may provide a solution for the difficult issue of utilization of wastewater from fishing 
farms, which, instead of becoming waste that requires disposal, may become a source of nutrients for biomass production [Keeratiurai, 2013]. Traditional wastewater treatment methods are costly solutions that generate a large amount of sludge, which in turn leads to problems with management or disposal [Vaillant, Monnet et al., 2003]. However, hydroponic systems are becoming more popular in wastewater treatment plants for small towns or villages as the third stage of treatment, thus supporting such traditional solutions as activated sludge or biofilm. Plant-based treatment systems that use the ability of macrophytes to uptake nutrients dissolved in wastewater are also applied at numerous industrial objects, mainly food processing plants in their treatment facilities.

Plants used in hydroponic installations usually originate from the region where the treatment plant is constructed. They are resistant to high pollutant loads that are changeable in time. Their main role is the final treatment of flowing wastewater by means of using adsorption and absorption processes [ $\mathrm{Li}$ et al., Asao 2012]. The direct role of plants in the wastewater treatment processes has been confirmed in numerous scientific studies that demonstrate that the level of accumulation of biogenic compounds, comparing to natural biogenes levels in selected plant tissues ranged from 18.97 to $57.40 \%$ for total nitrogen and from 17.60 to $42.54 \%$ for total phosphorus [Adrover et al. 2013, Oyama et al. 2005, Snow et al. 2008, Shelef 2013].

The use of the natural environment for wastewater treatment purposes is quite common. Most popular solutions are small wastewater treatment installations that combine the operation of soil and plant environment. [Dębska, Jóźwiakowski et al., 2015] These systems, which are popular throughout the world, are used not only for the purposes of domestic wastewater treatment but also for the treatment of landfill leachate and leachate from fields [Wareżak 2013, Wójcik W. 2013, Ebrahimi 2013]. The aim of this study is to present the effects of the treatment obtained for plants using the hydroponic technology (which is not very popular in Poland) with respect to possible seasonal changes.

\section{RESEARCH OBJECTS}

The analysis of the seasonal changes in the effectiveness of the reduction of nitrogen and phosphorus compounds from wastewater was conducted basing on the data obtained from hydroponic wastewater treatment plants located in Poland and Hungary, using the BIOPAX and Organica technology.

The first analyzed object is located in the town Paczkow, in the south-western part of the Opolskie Voivodeship. The community Paczkow borders the Lower Silesian Voivodeship on the north and west and the Czech Republic on the south. The wastewater treatment plant was constructed and put into service in 1999. The design capacity allows it to accept wastewater from an equivalent of 22396 inhabitants. Currently, it accepts municipal sewage from approx. 7000 inhabitants of the community, of which approx. $51 \%$ is covered by the sewage system. Daily capacity equals approx. $2500 \mathrm{~m}^{3} / \mathrm{d}$. The plant accepts, on average $1350 \mathrm{~m}^{3}$ of wastewater daily, of which 500-700 $\mathrm{m}^{3}$ are delivered by slurry tanks. After a three-stage treatment process, the wastewater is discharged by a system of drainage ditches to the Nysa Kłodzka River.

The first stage of wastewater treatment consists of screens and a separator whose task is to remove solid contaminants. The next stage consists in biological treatment that takes place in a circulation hybrid biological reactor, using both suspended biomass (activated sludge flocks) and submerged biofilters (settled biomass). The reactor is divided into three functional zones - anaerobic zone on the inlet and alternately placed anoxic and aerobic zones, where the processes of nitrification and denitrification take place. The aeration of aerobic zones occurs basing on jet aerators that are characterized by lower energy consumption, in comparison to other aeration systems [Sadecka, Waś, 2007]. After the sedimentation process that takes place in the secondary settling tank, wastewater is directed to a flow hydroponic lagoon constituting the third stage of treatment in the technological chain. The river bed of the lagoon has been shaped to resemble an artificial river, and its working capacity is $530 \mathrm{~m}^{3}$, which allows for a five-hour flow of wastewater [Zawałek, 2010]. Floating panels (app. $2.0 \times 2.0 \mathrm{~m}$ ) covers $70 \%$ of hydroponic lagoon surface. They are overgrown by macrophytes like Pistia stratiotes, Myriophyllum verticillatum, Limnobium laevigatum and Eichhornia crassipes. Additionaly submerged vertical panels overgrown by periphytic algae are installed to separate individual sectors and improve $\mathrm{N}$ and P removal. The flow lagoon is isolated from atmospheric conditions that might 
have a negative influence on treatment effectiveness with polycarbonate panes which provide a greenhouse effect - high solar irradiation, high temperature (up to $40{ }^{\circ} \mathrm{C}$ in the summer) and high air humidity (60-90\%). The task of this «artificial river» is to provide final treatment of wastewater discharged from the secondary settling tank through self-purification processes that occur in natural river ecosystems as a result of the activity of microorganisms, aquatic organisms and plants, additionally intensified by aeration.

The Hungarian object is a wastewater treatment plant located in the town of Szarvas, in the southeastern part of Hungary, in the Békés comitate. It is a hydroponic plant that has been operating since 2008, accepting industrial wastewater from the Gallicoop poultry processing plant. The size of the object expressed as a number of population equivalent is 6200 and its capacity equals $1100 \mathrm{~m}^{3} / \mathrm{d}$ Treated wastewater is discharged to an adjacent stream.

The first stage of treatment in Organica systems (also known under the name Veolia System) is pre-treatment with the use of grills, screens and in a grit separator. After balancing the outflow, the wastewater is directed to the pre-reactor in form of an anaerobic tank. This is where the denitrificationand sedimentation processes take place. Pretreated wastewater is then directed to the main reactor - aerobic tank - where the processes of COD removal, nitrification and biological dephosphatation occur. The aerobic tanks are covered by floating supporting grids, overgrown with plants with well-developed root systems directly submerged into the wastewater to the depth of approx. $1.5 \mathrm{~m}$. Such root systems enable macrophytes to uptake nitrogen and phosphorus compounds that are present in the wastewater and the roots themselves constitute a support for developing bacteria, algae, protozoa and even slugs or clams. The whole treatment facility is located under a greenhouse roof, which provides optimal climate conditions for plant vegetation and for the activity of all kinds of organisms responsible for the wastewater treatment processes throughout the year.

\section{RESULTS AND DISCUSSION}

The analyzed results of tests of the effectiveness of the reduction of biogenic compounds from wastewater for the wastewater treatment plants in Paczkow and in Szarvas encompass a three-year period: 2009-2011. Neither the Polish nor the Hungarian facility is required to maintain appropriate concentrations of nitrogen and phosphorus in water discharged from the plant. Analyses of the concentration of various forms of total nitrogen and phosphorus are carried out as ordered by plant managers in order to control the effectiveness of the conducted treatment processes. Analyzes of total nitrogen and total phosphorus in wastewater from Paczkow WWTP were made with the use of research methods commonly used in Poland: PN-73/C-04576.14 and PN-EN ISO 6878:2006. Analyzes of biogenes concentrations in wastewater from WWTP in Szarvas were based on rapid tests - test with Nessler's Reagent for ammonia nitrogen and test with VM Phosphate Reagent for total phosphorus concentration.

Table 1. Concentrations of nitrogen and phosphorus compounds in raw wastewater from wastewater treatment plants in Paczków and Szarvas in years 2009-2011

\begin{tabular}{|c|c|c|c|c|}
\hline Specification & $\begin{array}{c}\text { Total nitrogen } \\
{\left[\mathrm{mg} / \mathrm{dm}^{3}\right]}\end{array}$ & $\begin{array}{c}\text { Total phosphorus } \\
{\left[\mathrm{mg} / \mathrm{dm}^{3}\right]}\end{array}$ & $\begin{array}{c}\text { Ammonia nitrogen } \\
{\left[\mathrm{mg} / \mathrm{dm}^{3}\right]}\end{array}$ & $\begin{array}{c}\text { Total phosphorus } \\
{\left[\mathrm{mg} / \mathrm{dm}^{3}\right]}\end{array}$ \\
\hline Facility & \multicolumn{2}{|c|}{ Paczków } & \multicolumn{2}{|c|}{ Szarvas } \\
\hline \multicolumn{5}{|c|}{2009} \\
\hline Average & 70,80 & 10,10 & 4,37 & 8,34 \\
\hline Min. & 44,30 & 7,15 & 2,38 & 5,52 \\
\hline Max. & 108,00 & 15,90 & 5,50 & 10,68 \\
\hline \multicolumn{5}{|c|}{2010} \\
\hline Average & 50,54 & 6,13 & 2,28 & 8,56 \\
\hline Min. & 8,46 & 2,37 & 0,68 & 5,88 \\
\hline Max. & 177,00 & 18,80 & 5,75 & 12,83 \\
\hline \multicolumn{5}{|c|}{2011} \\
\hline Average & 67,33 & 8,76 & 6,10 & 8,77 \\
\hline Min. & 39,00 & 5,39 & 2,03 & 6,50 \\
\hline Max. & 92,00 & 21,40 & 9,25 & 11,83 \\
\hline
\end{tabular}


The concentration of biogenic compounds in raw and treated sewage from the wastewater treatment plant in Paczkow is tested once a month at an accredited laboratory in Pszczyna. The quality of raw and treated sewage from the facility in Szarvas is tested in an on-site laboratory. These tests include the determination of total phosphorus, ammonium and nitrate nitrogen. The results of tests of raw sewage flowing into the plants in Paczkow and Szarvas are presented in Table 1.

The tests results of the quality of raw sewage in the Polish and Hungarian objects show that the analyzed outflows from both plants are characterised by similar values of total phosphorus concentration. As far as the concentration of nitrogen compounds is concerned, the plant in Paczkow was characterised by high concentrations of this element in raw sewage. The changes within the analysed period ranged from $67.33-70.80 \mathrm{mg} /$ $\mathrm{dm}^{3}$. For the plant in Szarvas, the analysed param- eter was ammonium nitrogen which maximum concentration in analyzed period reached 9.25 $\mathrm{mg} / \mathrm{dm}^{3}$ in 2011. Ammonia nitrogen in domestic wastewater comes mostly from biochemical decomposition of organic compounds and may constitute up to $60 \%$ of total nitrogen [Jordanowska, Jakubus 2013]. Concentrations of total nitrogen as well as ammonia nitrogen in poultry processing wastewater can be double or even triple the concentrations of those compounds found in domestic sewage [Canter, Harfouche, 2000].

Mean effectiveness of the reduction of biogenes in summer and winter months and throughout the year is presented in Figures 1 and 2. Data shown in the diagram demonstrate that in the years 2009 and 2010 the highest effectiveness of total nitrogen reduction was obtained in winter months, while the lowest - in summer. However, it was expected that the results would be similar as in 2011, when the highest effectiveness of total nitrogen concentration

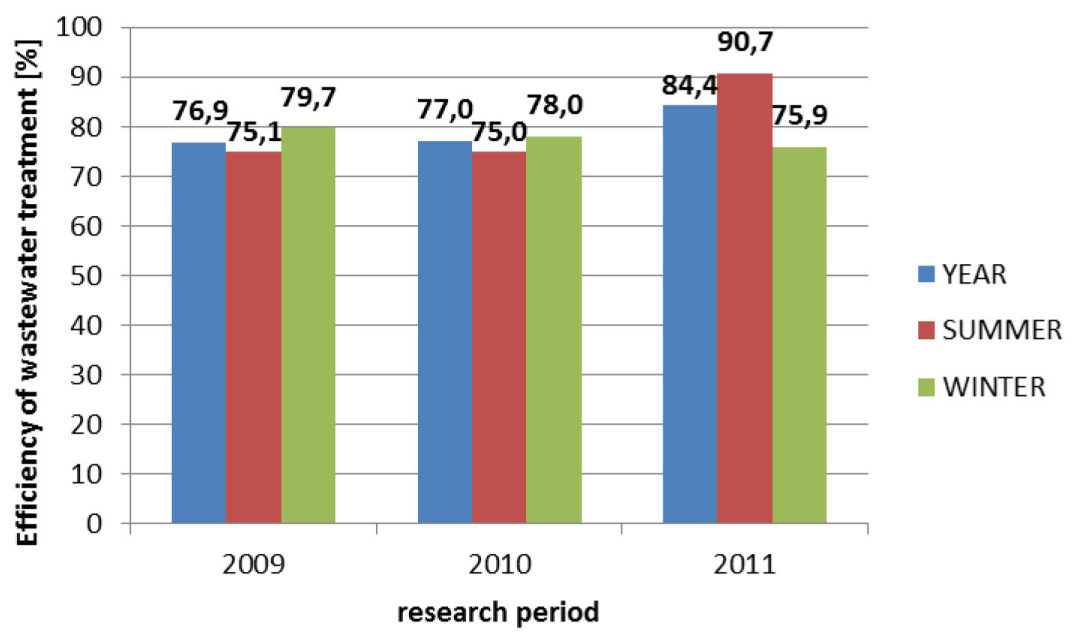

Figure 1. Average efficiency of total nitrogen removal in hydroponic wastewater treatment plant in Paczków, in summer, winter and throughout the year, during the research study from 2009 to 2011

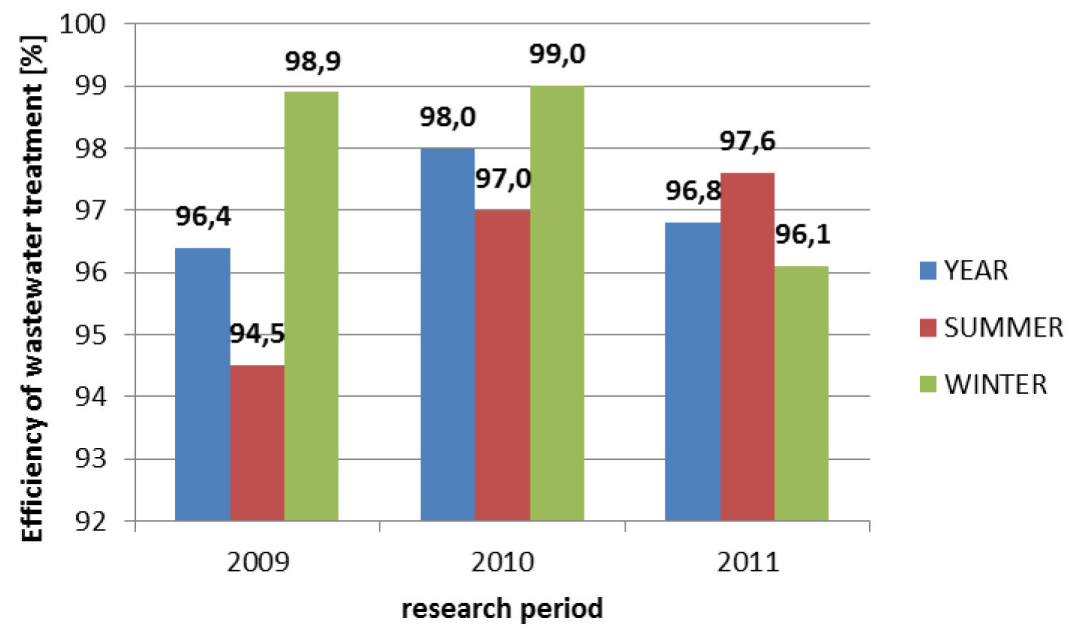

Figure 2. Average efficiency of total phosphorus removal in hydroponic wastewater treatment plant in Paczków, in summer, winter and throughout the year, during the research study from 2009 to 2011 
reduction was noted in summer months, and the lowest - in winter. Such distribution of the effectiveness of the reduction of biogenes was forecasted basing on the time and duration of the vegetation period of plants inhabiting the hydroponic lagoon.

The distribution of effectiveness of phosphorus reduction from wastewater is similar to that of total nitrogen (Figure 2). In two initial years of observations (2009 and 2010) the lowest effectiveness of total phosphorus concentration reduction was obtained in winter months, while the lowest values were noted in the summer period. In the last year of observations the highest effectiveness was noted in summer, and the lowest in the winter period. As far as phosphorus reduction is concerned, mean reduction effectiveness exceeds $94 \%$ and it is much higher than the nitrogen reduction ability, which is connected with the existence of additional phosphorus reduction processes in the technological chain.
The plant located in Szarvas, Hungary, uses wholly natural treatment processes for organisms connected with the aquatic ecosystem and plants, without any chemical support. Apart from COD values and the concentration of total suspended solids, also analyses of ammonium nitrogen and total phosphorus concentration in wastewater are used for the purposes of quality control of the treatment process. Effectiveness of ammonium nitrogen reduction on the system is significantly higher than for the reduction of total phosphorus. In winter months, in all the analyzed years, it sometimes occurred that the phosphorus was released to the system instead of being eliminated (which results in negative values of treatment effectiveness). Considering the fact that the highest amounts of phosphorus were released in January and December, when air temperature is the lowest, and the fact that the wastewater treatment plant does not use any heating systems in winter

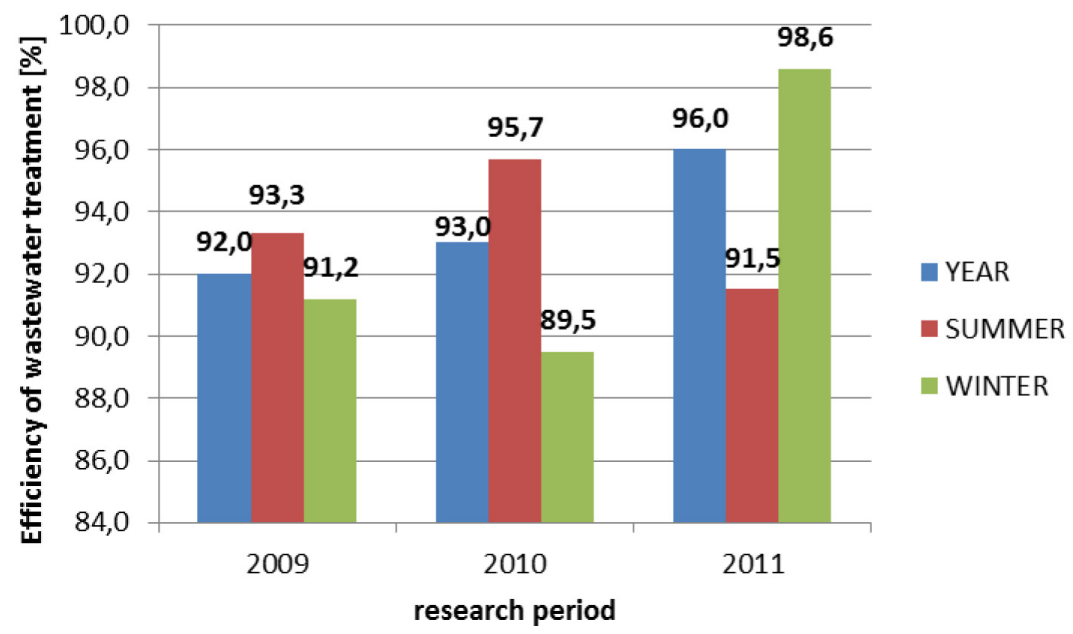

Figure 3. Average efficiency of ammonium nitrogen removal in hydroponic wastewater treatment plant in Szarvas, in summer, winter and throughout the year, during the research study from 2009 to 2011

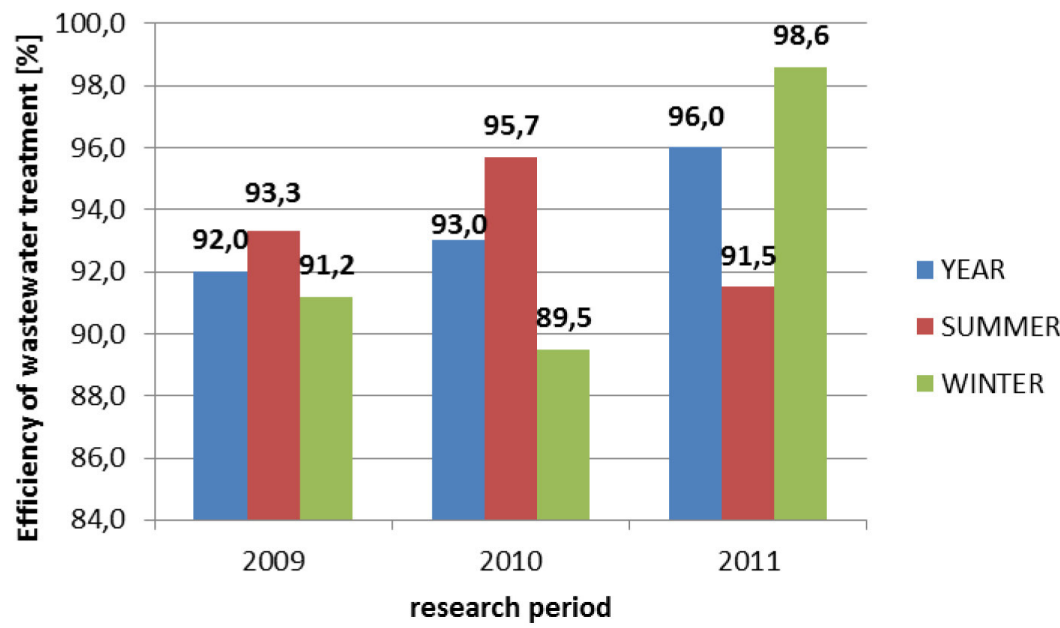

Figure 4. Average efficiency of total phosphorus removal in hydroponic wastewater treatment plant in Szarvas, in summer, winter and throughout the year, during the research study from 2009 to 2011 
months, it may be concluded that the decreased effectiveness of phosphorus reduction on the outflow was caused by climatic factor. Mean annual effectiveness of biogenes reduction from wastewater and operating effectiveness in the summer and winter periods is presented in Figures 3 and 4.

Data shown in the diagram demonstrate the changeability of the mean ability to reduce ammonium nitrogen in the plant based on Organica technology, with the use of natural self-purification processes supported by solar energy. In the years 2009 and 2010 the highest mean effectiveness of the reduction of ammonium nitrogen was noted in the summer period, when the activity of microorganisms and plants is the highest. In the colder part of the year, a decrease in the effectiveness of the reduction of this pollutant was noted in comparison to both the whole year and to the summer period. A reverse trend was observed in 2011, when the highest effectiveness of reduction of ammonium nitrogen was noted in winter months and was much higher than the average for summer.

\section{CONCLUSIONS}

The observations of the operation of the facilities and physical and chemical analyses of the content of sewage subject to treatment with the use of hydroponic technology led to the following conclusions:

1. The hydroponic wastewater treatment plant in Paczkow had a high mean annual effectiveness of the reduction of pollutants (nitrogen and phosphorus compounds): $75.6 \%$ for total nitrogen and $96.8 \%$ for total phosphorus.

2. In the summer half-year (2009-2010) the mean annual effectiveness of the reduction of nitrogen compounds was lower than in the winter period. A reverse trend was observed in 2011. The system capability for the reduction of phosphorus compounds was similar.

3. Mean annual levels of the reduction of nitrogen and phosphorus compounds for the facility in Szarvas in the analyzed period amounted to $92.8 \%$ - ammonium nitrogen and $51.2 \%$ for total phosphorus.

4. In the years 2009 and 2010 in the summer half-year a higher effectiveness of the reduction of both ammonium nitrogen and total phosphorus was noted, in comparison to win- ter months. In 2011 the winter half-year was characterized by a higher effectiveness of reduction of biogenic compounds.

\section{Acknowledgments}

Authors would like to thank the management of Wastewater Treatment Plant in Szarvas, Hungary and Wastewater Treatment Plant in Paczkow, Poland, for giving the access to data and materials that were essential for this publication.

\section{REFERENCES}

1. Adrover M. et al. 2013. Use of hydroponics culture to assess nutrient supply by treated wastewater. Journal of Environmental Management 127, 162-165.

2. Asao T. 2012. Hydroponics - a standard methodology for plant biological researches. InTech Croatia, pp. 244.

3. Canter L.W. and N. Harfouche, 2000. Sources and Characteristics. In: D.H.F. Liu and and B.G. Liptak (Eds.) Wastewater Treatment. Lewis Publishers, New York, 114-142.

4. Dębska A., Jóźwiakowski K., Gizińska-Górna M., Pytka A., Marzec M., Sosnowska B., Pieńko A. 2015. The fficiency of pollution removal from domestic wastewater in constructed wetland systems with vertical flow with common reed and glyceria maxima. Journal of Ecological Engineering, 16(5), 2015, 110-118.

5. Ebrahimi A. et al. 2013. Efficiency of Constructed Wetland Vegetated with Cyperus alternifolius Applied for Municipal Wastewater Treatment. Journal of Environmental and Public Health, Vol. 2013, 1-5.

6. Parzych A.E., Cymer M., Jonczak J., Szymczyk S. 2015. The ability of leaves and rhizomes of aquatic plants to accumulate macro- and micronutrients. Journal of Ecological Engineering 16(3), 198-205.

7. Shelef O. et al. 2013. Role of Plants in a constructed wetland: Current and new perspectives. Water, 5, 405-419.

8. Jordanowska J., Jakubus M. 2013. Ładunki zanieczyszczeń oraz efektywność oczyszczania ścieków komunalnych z rejonu Wrześni na przestrzeni lat. Nauka Przyr. Technol. 7, 3, \#32 (in Polish).

9. Keeratiurai P. 2013. Efficiency of wastewater treatment with hydroponics. ARPN Journal of Agricultural and Biological Science, 8(12), 800-805.

10. Monnet F., Vaillant N., Hitmi A., Vernay P., Coudret A., Sallamon H. 2002. Treatment of domestic wastewater using the nutrient film technique (NF) 
to produce horticultural roses. Water Research, 36, 3489-3496.

11. Oyama, N., Nair, J., Ho, G.E., 2005. Recycling of treated domestic effluent from an onsite wastewater treatment system for hydroponics. Water. Sci. Technol. 51(10), 220-221.

12. Rababah A.A., Ashbolt N.J. 2000. Innovative production treatment hydroponic farm for primary municipal sewage utilization. Water Research 34(3), 825-834.

13. Sadecka Z., Waś J. (2007. Procesy tlenowo - beztlenowe w cyrkulacyjnym przepływowym reaktorze biologicznym. Oczyszczanie ścieków i przeróbka osadów ściekowych, red. Z. Sadecka, S. Myszograj - Zielona Góra. Oficyna Wydaw. Uniwersytetu Zielonogórskiego, 71-78.
14. Snow, A.M., Ghaly, A.E., 2008. Use of barley for purification of aquaculture wastewater in a hydroponics system. Am. J. Environ. Sci. 4, 89-102.

15. Vaillant N., Monnet F., Sallamon H., Coudret A., Hitmi A. 2003. Treatment of domestic wastewater by an hydroponic NFT system. Chemosphere 50, 121-129.

16. Warężąk T. et al. 2013. Skuteczność oczyszczania ścieków w oczyszczalni hydrofitowej typu VF-CW. Rocznik Ochrona Środowiska 2013, tom 15, 1243-1259 (in Polish).

17. Wójcik A.W. 2010. Landfill leachate treatment using constructed wetland with short detention time. Archives of Environmental Protection 36(3), 51-58.

18. Zawałek T. 2010. Czy oczyszczalnia ścieków może być bardziej Eko? Forum Eksploatatora, 1112, 36-38 (in Polish). 